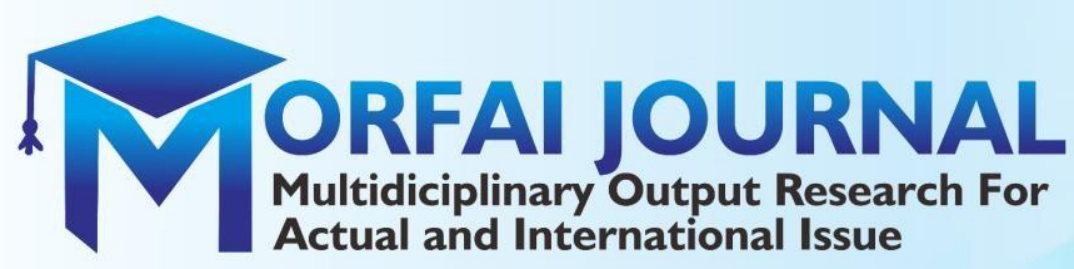

\title{
ANALYSIS OF FACTORS AFFECTING E-COMMERCE CUSTOMER PURCHASE DECISIONS
}

\author{
Rini Astuti ${ }^{1}$, Delyana R Pulungan² \\ ${ }^{1}$ Management Study Program, Universitas Muhammadiyah Sumatra Utara, Medan, Indonesia \\ ${ }^{2}$ Plantation Cultivation Study Program, Sekolah Tinggi Ilmu Pertanian Agribisnis Perkebunan, Medan, \\ Indonesia \\ E-mail: ${ }^{1}$ riniastuti@umsu.ac.id
}

\begin{abstract}
The purpose of this study was to determine and analyze the effect of Promotion, Ease of Use and Trust on Purchase Decisions for Shopee E-Commerce Customers in Medan City. The approach used in this study is an associative approach. The population in this study were E-Commerce Shopee Customers in Medan City as many as 100 customers while the sample in this study used Nonprobability sampling or Saturated Sampling as many as 100 people.The data collection technique used in this study is a questionnaire/questionnaire. The data analysis technique in this study uses Multiple Linear Regression Test, Hypothesis Testing ( $\mathrm{t}$ Test and F Test), and Coefficient of Determination. Data processing in this study uses the support of the SPSS software program. The results of this study prove that partially Promotion (X1) has a significant effect on Purchase Decisions (Y), Partially Ease of Use (X2) has a significant effect on Purchase Decisions (Y), Partial Trust has a significant effect on Purchase Decisions (Y). And Simultaneously Promotion, Ease of Use and Trust have a positive and significant impact on Purchase Decisions for Shopee E-Commerce Customers in Medan City.
\end{abstract}

Keywords: Promotion, Ease of Use, Trust and Purchase Decision

\section{INTRODUCTION}

At this time the development of technology in Indonesia is increasingly rapidly accompanied by business developments that are increasingly rapid as well. This requires a company in developing and maintaining its business to continue to think creatively and innovatively and be responsive to technology in order to be able to compete in the business world. Not only that, with the development of technology and business, it certainly has an impact on an existing system, one of which is the buying and selling system or transactions that are usually done conventionally are now electronic. This is supported by the increasing number of internet users. Indonesia itself is ranked 6th as the country with the largest internet users in the world.

The behavior of people who are starting to pay great attention to online shopping provides benefits for several parties, both producers and consumers. For the producers they get benefits such as ease in promoting their products or services. They do not need to spend more capital to open a shop. For consumers themselves, with their online shopping system, they can save time and effort as well as a large selection of products or services that match the price consumers want without having to bargain.

One of the most popular e-commerce sites in Indonesia is Shopee e-commerce. Shopee is the largest e-commerce platform in Southeast Asia and Taiwan with 10 million active users founded by Forrest Li in 2009 and currently led by Chris Feng who is headquartered in Singapore under the SEA Group (formerly known as Garena). In 2015 Shopee was first launched in Singapore and since then Shopee has expanded its reach to other Asian countries such as Malaysia, Taiwan, Thailand and others 
including Indonesia. Shopee comes in the form of an application that makes it easy for users to carry out shopping activities or carry out online transactions practically without having to spend a lot of energy to get a product that the user wants.

Quoted from(Jayani, 2020), it seems that Shopee dominates the market e-commercebased on the number of monthly visits in the second quarter of 2020. The average visit per month is 93.4 million. In addition, Shopee is ranked first in the AppStore and Playstore. Shopee also managed to win an award in the form of "The Indonesian Netizen Brand Choice Award 2017" or the award for the chosen brand of Indonesian netizens held by Warta Ekonomi for the Online Shopping category in March 2017.

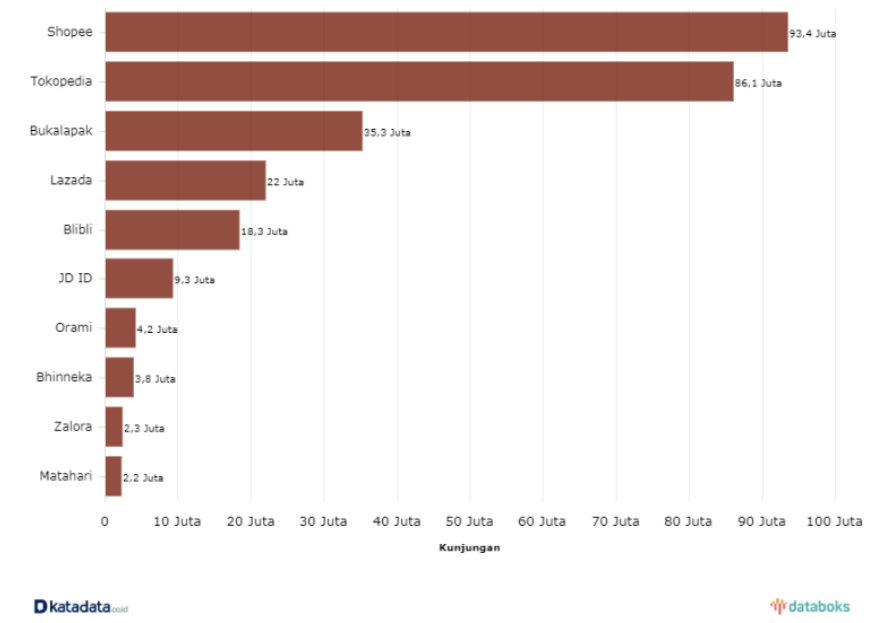

Figure 1 E-Commerce Competition Map in Indonesia in Second Quarter 2020

From the graph above, it can be seen that Shopee excelled in e-commerce competition in Indonesia in the second quarter of 2020. Quoted from (Catriana, 2020), Handhika Jahja as Director of Shopee Indonesia, said that in the second quarter of 2020, Shopee's transaction volume reached 260 million transactions or an average of 2.8 million transactions per day. Compared to the second quarter of 2019 , this figure increased by $130 \%$. This e-commerce business also achieved substantial revenue in the second quarter of 2020. In the results of the financial statements, the company's total revenue was recorded at US\$510.6 million, an increase of $187.7 \%$ compared to the same period in 2019. The number of Shopee transaction volumes globally also increased by $150.1 \%$ year-on-year, with a total of 615.9 million transactions. This increase is much higher than the first quarter of 2020 which was only $111.2 \%$ year-on-year.

There are many factors that influence consumer purchasing decisions. according to(Kotler \& Armstrong, 2001)there are two factors that influence consumer purchasing decisions, namely (1) internal factors including promotion and (2) external factors including trust. In addition, based on research conducted by(Prayudha \& Suwitho, 2019) states that online purchasing decisions are influenced by several factors, one of which is convenience.

Promotion is a form of marketing communication to provide information about a product or service to target customers with the aim of influencing, persuading and reminding about a product or service being offered.(Son, 2019). Promotion has a very important role because promotion is a determining factor for the success of a company in marketing a product or service. Promotion can be used as a way to attract new consumers and maintain customer loyalty because many customers switch to a certain brand just because a promotion is in the form of a cheaper price and is considered more attractive. 


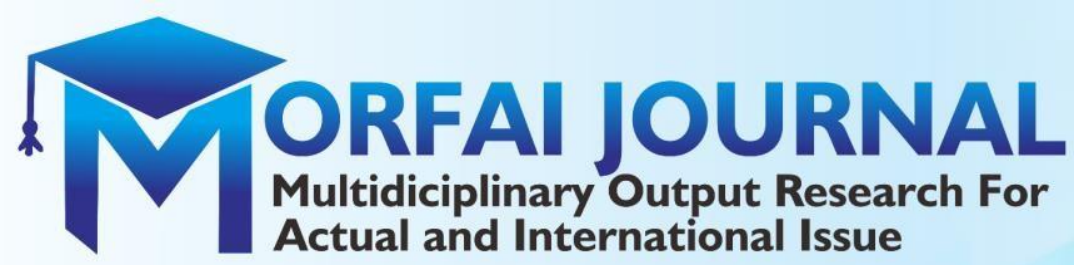

The purpose of this study is to determine and analyze the effect of Promotion, Ease of Use and Trust on Purchase Decisions for Shopee E-Commerce Customers in Medan City.

\subsection{Buying decision}

Decision Purchasing is a decision taken when someone feels interested in a particular product and wants to buy, try or use the product which usually when deciding to buy consumer goods has more than two parties participating in the buying process.(Marlius, 2017).

according to(Kotler \& Armstrong, 2001) There are several factors that influence consumer behavior towards decision making, namely:

\section{External Factors}

a. Cultural factors, which include an understanding of the role of culture, sub-culture and social class

b. Social factors, namely factors that include small groups, families and the role and social status of consumers

c. Personal factors, which include various personal characteristics such as age and cycle stage, occupation, economic situation, lifestyle and personality and self-concept

d. Psychological factors, namely factors that influence a person's choice in buying which includes motivation, perception, knowledge and beliefs or beliefs and attitudes

\section{Internal factors}

a. Income, which is a factor that has an influence on a person to determine the place where they should shop

b. Service, which is one of the most important factors to determine success in serving consumers in the hope of achieving customer satisfaction for the services that have been provided

c. Price, which is a factor that influences consumer buying interest because price is part of the determining factor in market demand for a product

d. Location, which is expected to be a strategic location close to consumers and easy transportation

e. Product, which is one of the factors that meet and satisfy the needs and desires of consumers

f. Promotion, which is one part of a series of marketing activities that encourage consumers to want to buy it, where the expected result is an increase in sales volume

\subsection{Promotion}

Promotion is one way that is often done by sellers to increase their sales volume. Promotion is an activity to convey or inform consumers about the benefits of a product and service with the aim of encouraging consumers to buy these products and services(Tajudin \& Mulazaid, 2017). according to(Septiani, 2018)Promotion is an attempt to influence the attitudes or behavior of potential consumers to persuade them with the hope that they can accept, buy or use the product being promoted. on the other hand(Hanum et al., 2021)argues that promotion is the foundation of business. Building promotions in long-term relationships with consumers is an important factor to create customer loyalty. This promotion cannot simply be recognized by other parties/business partners, but must be built from scratch and can be proven. Promotion is also a way to persuade potential buyers to make transactions with sellers to achieve the company's goal of making a profit(I. Rasyadi, 2017).

according to(Private \& Irawan, 2008) the factors that influence the implementation of the promotion are:

1. Available funds

A company with sufficient funds can make advertising programs more effective than a company with limited funding sources. And for small companies or those with weak finances, they will control advertising more than the use of personal selling. 
Analysis Of Factors Affecting E-Commerce Customer Purchase Decisions

DOI: $10.54443 /$ morfai.v1i2.114

2. Market nature

Some of the market characteristics that affect this promotional mix include:

a. Market geographic area

b. Customer type

c. Market concentration

3. Product nature

The nature of this product will affect the company's strategy whether the product is in the form of production or industrial goods

4. Stages in the product life cycle

The product life cycle includes: introduction stage, growth stage, maturity stage and decline stage. Which of each of these stages has a different character from one another, so that the promotion strategy carried out for each stage is different.

\subsection{Ease of Use}

according to(Davis, 1989)Perceived ease of use can be interpreted as the extent to which individuals believe that using a particular system/technology will be free from difficulties and a great effort. Ease of use is certainly an important factor influencing purchasing decisions. In online purchasing decisions, it is believed that when consumers feel positive convenience they will tend to cause attitudes towards the decision to shop online(Suleman et al., 2019). Ease of use in this context is not only the ease of learning and using a system but also refers to the ease of doing a job or task where using a system will make it easier for someone to work compared to doing it manually.(Bahri \& Listiorini, 2019). on the other hand(Suhardi \& Taufik, 2018) argues that ease of use is part of the technology acceptance model (TAM) which has the perception that a person's behavior is related to the usability of a technology to analyze the information technology adaptation process.

according to(Istiarni \& Hadiprajitno, 2014) The ease of using technology is influenced by several factors, namely:

1. The first factor focuses on the technology itself. A good technology and used continuously will make it easy for users to use it. For example, the user experience of using similar technology will provide user convenience.

2. The second factor is the reputation of the technology earned by the users. A good reputation that is heard by users will encourage user confidence in the ease of use of the technology.

3. The third factor that influences user perceptions of the ease of using technology is the availability of reliable support mechanisms. A trusted support mechanism will make users feel comfortable and confident, that there is a reliable support mechanism in case of difficulties in using technology, thus encouraging user perceptions in a more positive direction.

\subsection{Trust}

Trust is the basis for business where when a business transaction between two or more parties occurs when they trust each other(Jayanti, 2015). according to(Hendra. \& Amin, 2019)Consumer trust is a belief that is believed by a consumer that other people have honesty and can be trusted and the person he trusts will carry out all his obligations related to the agreed transaction in accordance with consumer expectations. on the other hand(Ayuningtiyas \& Gunawan, 2018) also argues that consumer trust is an individual's willingness to accept the risk of actions taken by other individuals in carrying out important actions in online transactions starting from the process of filling out forms and processing payments.

according to(Yuliawan et al., 2018) The factors that influence consumer confidence in a company are as follows:

\section{Trusting Belief}




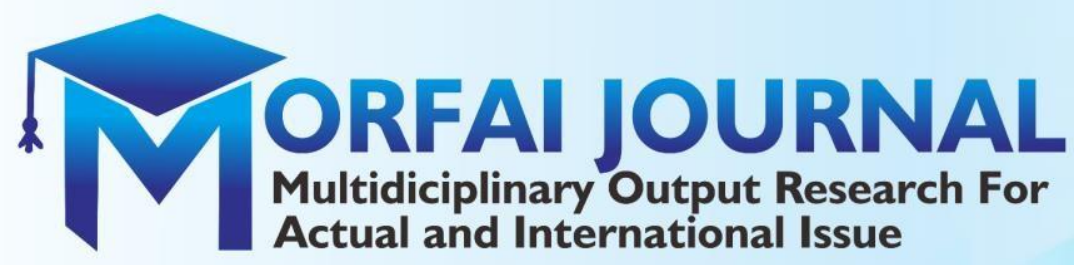

Trusting Belief namely the perception of the trusting party (consumer) of the trusted party in which the seller has characteristics that will benefit consumers. There are three elements that build trusting belief, namely as follows:

a. Benevolence

Benevolence is the seller's willingness to serve the interests of consumers by satisfying consumers

b. Integrity

Integrity that is how much someone believes in the honesty of the seller to maintain and fulfill the agreement that has been made to the consumer.

c. Competence

Competence or competence is a person's belief in the ability of the seller to assist consumers in doing something according to what the consumer needs.

2. Trusting Intention

Trusting Intentionie an intentional thing where a person is ready to depend on another person in a situation, this happens personally and leads directly to the other person. There are two elements that build trusting intention, namely as follows:

a. Willingness to depend

Willingness to depend is the willingness of consumers to depend on the seller in the form of accepting the risk or negative consequences that may occur.

b. Subjective probability of depending

Subjective probability of depending is the subjective willingness of consumers in the form of providing personal information to sellers, conducting transactions, and being willing to follow suggestions or requests from sellers.

\section{METHOD}

\subsection{Types of research}

In this research, the type of research used is quantitative research with associative problem formulation. Quantitative research is research based on facts in the field and then realized into a hypothesis or theory that is used to examine a particular population or sample in which research instruments are used for data collection, quantitative or statistical data analysis that aims to test predetermined hypotheses.(Sugiyono, 2017).

In this research used survey method. The survey method is the method most often used, namely by using a questionnaire as an instrument to collect data(Sandu \& Sodik, 2015). This survey research was conducted by going directly to the field to distribute questionnaires or questionnaires to the public as an instrument of data collection and processed using SPSS. This method focuses on collecting data from respondents who have certain information so as to enable researchers to understand and be able to solve problems.

\subsection{Place and time of research}

This research was conducted in Medan City, North Sumatra Province.

The time in this research was carried out from January 2020 to January 2021.

\subsection{Population}

The population in this study are customers who use Shopee e-commerce in Medan City.

\subsection{Sample}

The sampling technique used is the Nonprobability Sampling technique with the Accidental Sampling method, which is a method of determining the sample based on chance, that is, anyone who 
coincidentally/incidentally meets the researcher can be used as a sample, if it is deemed that the person who happened to be met is suitable as a data source. (Sugiyono, 2017). So, this research was conducted with anyone who would be met by chance as a sample. Respondents who will be the sample are respondents who have used Shopee e-commerce in Medan City. The number of samples taken as many as 100 respondents (shopee customers) with the provision that the number of samples is the most ideal for correlation analysis.

\section{RESULTS AND DISCUSSION}

\subsection{Description of Research Variables}

\subsubsection{Variable Y (Purchase Decision)}

To be more helpful, the following authors present a table of the results of the scores of respondents' answers from the questionnaires that the authors distribute, namely:

Table 3.1

Questionnaire Score for Variable Y (Purchase Decision)

\begin{tabular}{|c|c|c|c|c|c|c|c|c|c|c|c|c|}
\hline \multirow{3}{*}{ No Statement } & \multicolumn{12}{|c|}{ Answer } \\
\hline & \multicolumn{2}{|c|}{$\begin{array}{l}\text { Strongly } \\
\text { agree }\end{array}$} & \multicolumn{2}{|c|}{ Agree } & \multicolumn{2}{|c|}{ Disagree } & \multicolumn{2}{|c|}{$\begin{array}{l}\text { Do not } \\
\text { agree }\end{array}$} & \multicolumn{2}{|c|}{$\begin{array}{l}\text { Strongly } \\
\text { Disagree }\end{array}$} & \multicolumn{2}{|c|}{ Amount } \\
\hline & $\mathrm{F}$ & $\%$ & $\mathrm{~F}$ & $\%$ & $\mathrm{~F}$ & $\%$ & $\mathrm{~F}$ & $\%$ & $\mathrm{~F}$ & $\%$ & $\mathrm{~F}$ & $\%$ \\
\hline 1 & 30 & 30.0 & 68 & 68.0 & 2 & 2 & 0 & 0 & 0 & 0 & 100 & 100.0 \\
\hline 2 & 52 & 52.0 & 43 & 43.0 & 5 & 5.0 & 0 & 0 & 0 & 0 & 100 & 100.0 \\
\hline 3 & 35 & 35.0 & 62 & 62.0 & 5 & 5.0 & 0 & 0 & 0 & 0 & 100 & 100.0 \\
\hline 4 & 29 & 29.0 & 67 & 67.0 & 4 & 4.0 & 0 & 0 & 0 & 0 & 100 & 100.0 \\
\hline 5 & 31 & 31.0 & 67 & 67.0 & 2 & 2 & 0 & 0 & 0 & 0 & 100 & 100.0 \\
\hline 6 & 50 & 50.0 & 44 & 44.0 & 6 & 6 & 0 & 0 & 0 & 0 & 100 & 100.0 \\
\hline 7 & 55 & 55.0 & 45 & 45.0 & 0 & 0.0 & 0 & 0 & 0 & 0 & 100 & 100.0 \\
\hline 8 & 23 & 23.0 & 62 & 62.0 & 15 & 15.0 & 0 & 0 & 0 & 0 & 100 & 100.0 \\
\hline
\end{tabular}

Source: Processed Research Data (2021)

From the table above can be described as follows:

1. Respondents' answers aboutI bought a product on Shopee out of necessity, most of the respondents answered agreed by $68.0 \%$.

2. Respondents' answers aboutI buy products on Shopee based on brand considerations, most of the respondents answered strongly agree at $52.0 \%$.

3. Respondents' answers aboutI feel Shopee's products match your needs and desires, most of the respondents answered agreed by $62.0 \%$.

4. Respondents' answers aboutI'm planning to re-purchase on Shopee, most respondents answered agree by $67.0 \%$.

5. Respondents' answers aboutI have the confidence to shop at Shopee, most of the respondents answered agree at $67.0 \%$.

6. Respondents' answers aboutI'm interested in using Shopee based on other people's experiences, some respondents answered strongly agree at $50.0 \%$.

7. Respondents' answers aboutI set the time in advance to make a purchase on Shopee, most of the respondents answered strongly agree at $55.0 \%$.

8. Respondents' answers aboutThe number of products I buy on Shopee is uncertain, most of the respondents answered agreed by $62.0 \%$. 
Table 3.2

Questionnaire Score for Variable X1 (Promotion)

\begin{tabular}{|c|c|c|c|c|c|c|c|c|c|c|c|c|}
\hline \multirow{3}{*}{$\begin{array}{c}\text { No } \\
\text { Statement }\end{array}$} & \multicolumn{12}{|c|}{ Answer } \\
\hline & \multicolumn{2}{|c|}{$\begin{array}{c}\text { Strongly } \\
\text { agree }\end{array}$} & \multicolumn{2}{|c|}{ Agree } & \multicolumn{2}{|c|}{ Disagree } & \multicolumn{2}{|c|}{$\begin{array}{l}\text { Do not } \\
\text { agree }\end{array}$} & \multicolumn{2}{|c|}{$\begin{array}{l}\text { Strongly } \\
\text { Disagree }\end{array}$} & \multicolumn{2}{|c|}{ Amount } \\
\hline & $\mathrm{F}$ & $\%$ & $F$ & $\%$ & $\mathrm{~F}$ & $\%$ & $\mathrm{~F}$ & $\%$ & $\mathrm{~F}$ & $\%$ & $\mathrm{~F}$ & $\%$ \\
\hline 1 & 18 & 18.0 & 71 & 71.0 & 11 & 11 & 0 & 0 & 0 & 0 & 100 & 100.0 \\
\hline 2 & 30 & 30.0 & 69 & 69.0 & 1 & 1.0 & 0 & 0 & 0 & 0 & 100 & 100.0 \\
\hline 3 & 8 & 8.0 & 83 & 83.0 & 9 & 9.0 & 0 & 0 & 0 & 0 & 100 & 100.0 \\
\hline 4 & 7 & 7.0 & 83 & 83.0 & 10 & 10.0 & 0 & 0 & 0 & 0 & 100 & 100.0 \\
\hline 5 & 35 & 35.0 & 65 & 65.0 & 0 & 0 & 0 & 0 & 0 & 0 & 100 & 100.0 \\
\hline 6 & 15 & 15.0 & 76 & 76.0 & 9 & 9 & 0 & 0 & 0 & 0 & 100 & 100.0 \\
\hline 7 & 31 & 31.0 & 67 & 67.0 & 2 & 2.0 & 0 & 0 & 0 & 0 & 100 & 100.0 \\
\hline 8 & 50 & 50.0 & 44 & 44.0 & 6 & 6.0 & 0 & 0 & 0 & 0 & 100 & 100.0 \\
\hline
\end{tabular}

Source: Processed Research Data (2021)

From the table above can be described as follows:

1. Respondents' answers aboutI feel that the price offered by Shopee is in accordance with the quality of the product, most of the respondents answered agreed by $71.0 \%$.

2. Respondents' answers aboutI feel that the price list provided by Shopee is quite affordable, most of the respondents answered agreed at $69.0 \%$.

3. Respondents' answers aboutThe special discount provided by Shopee is quite helpful, most of the respondents answered agree at $83.0 \%$.

4. Respondents' answers aboutThe promotional media used by Shopee is quite good, most of the respondents answered agree by $83.0 \%$.

5. Respondents' answers aboutThe frequency of promotions carried out by Shopee is quite frequent, most of the respondents answered agreed by $65.0 \%$.

6. Respondents' answers aboutThe free shipping offer given made me use Shopee, most of the respondents answered agreed by $76.0 \%$.

7. Respondents' answers aboutPromotion time available on Shopee is quite limited, most of the respondents answered agree at $67.0 \%$.

8. Respondents' answers aboutThe promotion by shopee is quite interesting, some respondents answered strongly agree at 50.0\%.

\subsubsection{Variable X2 (Ease of Use)}

Table 3.3

Questionnaire Score for Variable X2 (Ease of Use)

\begin{tabular}{|c|c|c|c|c|c|c|c|c|c|c|c|c|}
\hline \multirow{3}{*}{$\begin{array}{c}\text { No } \\
\text { Statement }\end{array}$} & \multicolumn{12}{|c|}{ Answer } \\
\hline & \multicolumn{2}{|c|}{$\begin{array}{c}\text { Strongly } \\
\text { agree }\end{array}$} & \multicolumn{2}{|c|}{ Agree } & \multicolumn{2}{|c|}{ Disagree } & \multicolumn{2}{|c|}{$\begin{array}{l}\text { Do not } \\
\text { agree }\end{array}$} & \multicolumn{2}{|c|}{$\begin{array}{l}\text { Strongly } \\
\text { Disagree }\end{array}$} & \multicolumn{2}{|c|}{ Amount } \\
\hline & $\mathrm{F}$ & $\%$ & $\mathrm{~F}$ & $\%$ & $\mathrm{~F}$ & $\%$ & F & $\%$ & $\mathrm{~F}$ & $\%$ & $\mathrm{~F}$ & $\%$ \\
\hline 1 & 10 & 10.0 & 84 & 84.0 & 6 & 6 & 0 & 0 & 0 & 0 & 100 & 100.0 \\
\hline 2 & 12 & 12.0 & 84 & 84.0 & 4 & 4.0 & 0 & 0 & 0 & 0 & 100 & 100.0 \\
\hline
\end{tabular}

Multidiciplinary Output Research For Actual and International Issue |MORFAI JOURNAL

EISSN: 2808-6635 I https//radjapublika.com/index.php/MORFAI 
Analysis Of Factors Affecting E-Commerce Customer Purchase Decisions

DOI: $10.54443 /$ morfai.v1i2.114

\begin{tabular}{|l|l|l|l|l|l|l|l|l|l|l|l|l|l|}
3 & 47 & 47.0 & 53 & 53.0 & 0 & 0.0 & 0 & 0 & 0 & 0 & 100 & 100.0 \\
\hline 4 & 48 & 48.0 & 52 & 52.0 & 0 & 0.0 & 0 & 0 & 0 & 0 & 100 & 100.0 \\
\cline { 2 - 14 } & 55 & 55.0 & 45 & 45.0 & 0 & 0 & 0 & 0 & 0 & 0 & 100 & 100.0 \\
6 & 23 & 23.0 & 62 & 62.0 & 15 & 15 & 0 & 0 & 0 & 0 & 100 & 100.0 \\
\hline 7 & 35 & 35.0 & 65 & 65.0 & 0 & 0.0 & 0 & 0 & 0 & 0 & 100 & 100.0 \\
\hline 8 & 15 & 15.0 & 76 & 76.0 & 9 & 9.0 & 0 & 0 & 0 & 0 & 100 & 100.0 \\
\hline
\end{tabular}

From the table above can be described as follows:

1. Respondents' answers aboutI think Shopee e-commerce is easy to learn, most of the respondents answered agreed by $84.0 \%$.

2. Respondents' answers aboutI think Shopee's e-commerce is easy to understand, most of the respondents answered agreed by $84.0 \%$.

3. Respondents' answers aboutI think Shopee e-commerce is easy to control according to my wishes, most of the respondents answered agreed by $53.0 \%$.

4. Respondents' answers aboutI find Shopee's e-commerce easy to operate, most of the respondents answered agree by $52.0 \%$.

5. Respondents' answers aboutI have no difficulties when using Shopee e-commerce, most of the respondents answered strongly agree at $55.0 \%$.

6. Respondents' answers about I feel Shopee's e-commerce is very flexible to use, some respondents answered agree by $62.0 \%$.

7. Respondents' answers about the Shopee e-commerce display are easy to read so that it is easy for me to understand, most of the respondents answered agree at $65.0 \%$.

8. Respondents' answers about I did not make continuous mistakes when operating Shopee ecommerce, some respondents answered agreed by $76.0 \%$.

\subsubsection{Variable X3 (Trust)}

Table 3.4

Questionnaire Score for Variable X3 (Trust)

\begin{tabular}{|c|c|c|c|c|c|c|c|c|c|c|c|c|}
\hline \multirow{3}{*}{$\begin{array}{c}\text { No } \\
\text { Statement }\end{array}$} & \multicolumn{12}{|c|}{ Answer } \\
\hline & \multicolumn{2}{|c|}{$\begin{array}{l}\text { Strongly } \\
\text { agree }\end{array}$} & \multicolumn{2}{|c|}{ Agree } & \multicolumn{2}{|c|}{ Disagree } & \multicolumn{2}{|c|}{$\begin{array}{l}\text { Do not } \\
\text { agree }\end{array}$} & \multicolumn{2}{|c|}{$\begin{array}{l}\text { Strongly } \\
\text { Disagree }\end{array}$} & \multicolumn{2}{|c|}{ Amount } \\
\hline & $\mathrm{F}$ & $\%$ & $\mathrm{~F}$ & $\%$ & $\mathrm{~F}$ & $\%$ & $\mathrm{~F}$ & $\%$ & $\mathrm{~F}$ & $\%$ & $\mathrm{~F}$ & $\%$ \\
\hline 1 & 31 & 31.0 & 67 & 67.0 & 2 & 2 & 0 & 0 & 0 & 0 & 100 & 100.0 \\
\hline 2 & 50 & 50.0 & 44 & 44.0 & 6 & 6.0 & 0 & 0 & 0 & 0 & 100 & 100.0 \\
\hline 3 & 35 & 35.0 & 65 & 65.0 & 0 & 0.0 & 0 & 0 & 0 & 0 & 100 & 100.0 \\
\hline 4 & 15 & 15.0 & 76 & 76.0 & 9 & 9.0 & 0 & 0 & 0 & 0 & 100 & 100.0 \\
\hline 5 & 55 & 55.0 & 45 & 45.0 & 0 & 0 & 0 & 0 & 0 & 0 & 100 & 100.0 \\
\hline 6 & 23 & 23.0 & 62 & 62.0 & 15 & 15 & 0 & 0 & 0 & 0 & 100 & 100.0 \\
\hline 7 & 35 & 35.0 & 65 & 65.0 & 0 & 0.0 & 0 & 0 & 0 & 0 & 100 & 100.0 \\
\hline 8 & 15 & 15.0 & 76 & 76.0 & 9 & 9.0 & 0 & 0 & 0 & 0 & 100 & 100.0 \\
\hline
\end{tabular}

Source: Processed Research Data (2021) 


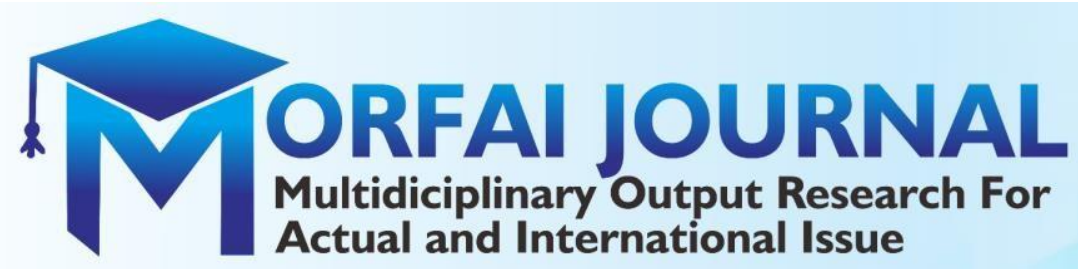

From the table above can be described as follows:

1. Respondents' answers aboutI think Shopee keep promises, behave ethically and honestly, most of the respondents answered agree by $67.0 \%$.

2. Respondents' answers aboutI'm sure Shopee can help find my needs, most of the respondents answered strongly agree at $50.0 \%$.

3. Respondents' answers aboutAccording to me Shopee can maintain and fulfill the agreements that have been made to consumers, most of the respondents answered agree at $65.0 \%$.

4. Respondents' answers aboutI'm sure Shopee will help solve the problems consumers face, most of the respondents answered agree by $76.0 \%$.

5. Respondents' answers about I can accept the risks or consequences that may occur, most of the respondents answered strongly agree at $55.0 \%$.

6. Respondents' answers aboutI believe that the product I buy meets my expectations, most of the respondents answered agreed by $62.0 \%$.

7. Respondents' answers aboutI believe in the guarantee that Shopee promises, most of the respondents answered agreed by $65.0 \%$.

8. Respondents' answers aboutI believe Shopee always provides the best for its consumers, most of the respondents answered agreed by $76.0 \%$.

\subsection{Data Analysis}

\subsubsection{Classical Assumption Test}

Multiple linear regression is known as some classical multiple regression assumptions or also known as BLUE (Best Linear Unbias Estimation). Classical assumption test simply aims to identify whether the regression is a good model or not. There are several tests of these classical assumptions, namely:

\subsubsection{Normality Test}

The normality test of the data was carried out to see whether in the regression model, the dependent and independent variables had a normal distribution or not. If the data spreads around the diagonal line and follows the direction of the diagonal line, the regression model meets normality.

\subsubsection{Histogram}

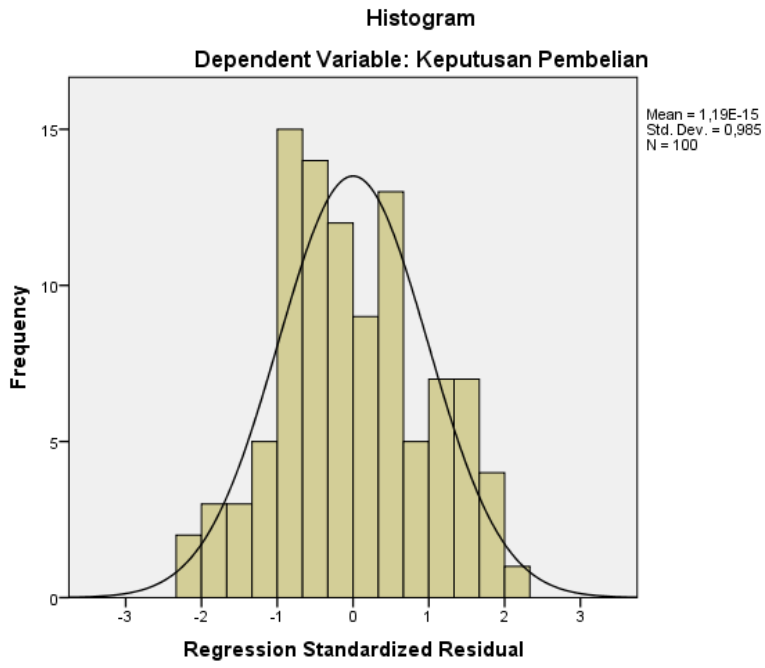

Source: Processed Research Data (2021) 


\section{Figure 3.1 Histogram Normality Test Results}

Based on the picture above, it can be seen that the histogram graph shows a good image of the data pattern. Standardized Residual Regression forms an image like a bell and follows the direction of the diagonal line so that it fulfills the classical assumption.

\subsubsection{P-Plot Normality}

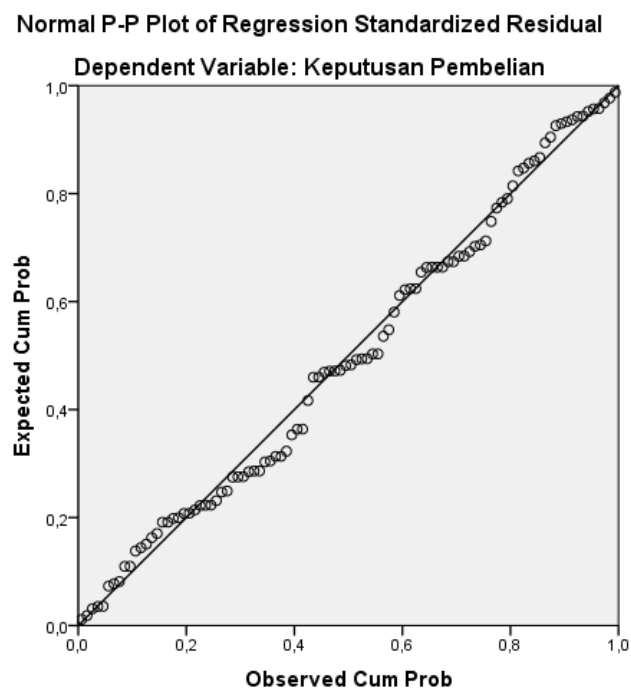

Source: Processed Research Data (2021)

Figure 3.2 Normality

The figure above identifies that the regression model has met the assumptions previously stated, so that the data in the research regression model tends to be normal.

\subsubsection{Multicollinearity Test}

Multicollinearity was used to test whether the regression model found a strong correlation between the independent variables. The method used to assess it is by looking at the value of the Variance Inflation Factor (VIF), which does not exceed 4 or 5.

Table 3.5

Multicollinearity Test

\begin{tabular}{|c|c|c|c|c|c|c|c|}
\hline \multirow[t]{2}{*}{ Model } & \multicolumn{2}{|c|}{ UnstandardizedCoefficients } & \multirow{2}{*}{$\begin{array}{c}\begin{array}{c}\text { Standardized } \\
\text { Coefficients }\end{array} \\
\text { Beta }\end{array}$} & \multirow[t]{2}{*}{$\mathrm{t}$} & \multirow[t]{2}{*}{ Sig } & \multicolumn{2}{|c|}{$\begin{array}{l}\text { Collinearity } \\
\text { Statistics }\end{array}$} \\
\hline & B & Std Error & & & & Tolerance & VIF \\
\hline (Constant) & 2,738 & 3,273 & & ,834 & 407 & & \\
\hline $\begin{array}{l}\text { Promotion } \\
\text { (X1) }\end{array}$ & ,474 & ,140 & 409 & 3,383 & , 001 & ,337 & 2,969 \\
\hline $\begin{array}{l}\text { Ease of Use } \\
\text { (X2) } \text { ource: }\end{array}$ & $\begin{array}{c}, 209 \\
\text { Processed Researd }\end{array}$ & $\begin{array}{c}, 134 \\
\text { Data }(2021) \\
\end{array}$ & ,172 & 1,667 & 003 & ,404 & 2,476 \\
\hline Trust (X3) & ,262 &, 183 & ,228 & 1,835 & ,004 & 195 & 5,136 \\
\hline Dependent Va & able : Purchase I & ecision & & & & & \\
\hline
\end{tabular}

Source:PhocetsedeRénedeplemedent(20arjables, namely X1, X2 and X3 have VIF values within a predetermined tolerance limit (not exceeding 4 or 5), so they do not become multicollinearity in the 


\section{TORFAI JOURNAL \\ Multidiciplinary Output Research For \\ Actual and International Issue}

independent variables of this study.

\subsubsection{Heteroscedasticity Test}

Heteroscedasticity is used to test whether in the regression model, there is an inequality of variance from another observation. If the residual variation from one observation to another is constant, it is called homoscedasticity, and if the variance is different it is called heteroscedasticity. A good model is that there is no heteroscedasticity.

The basis for making the decision is if a certain pattern such as the existing points forms a certain regular pattern, then heteroscedasticity occurs. If there is no clear pattern, and the points (points) spread below 0 on the $\mathrm{Y}$ axis, there is no heteroscedasticity.

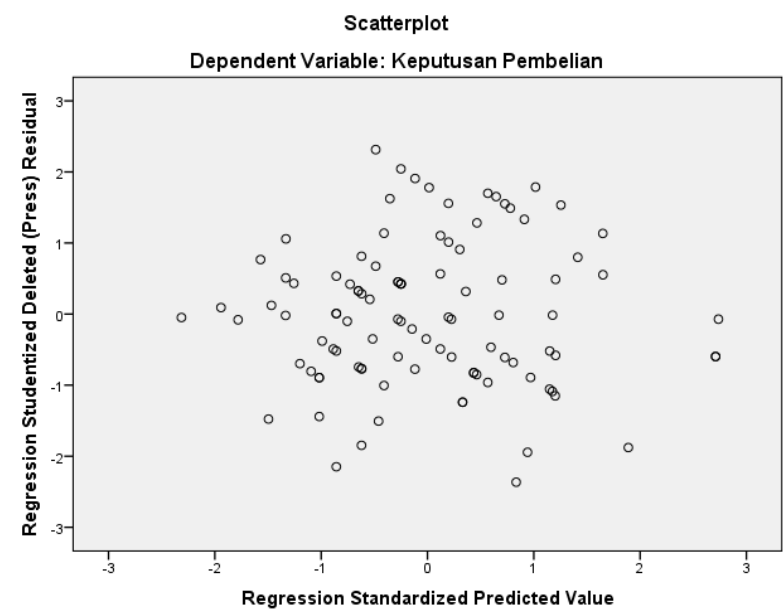

Figure 3.3 Heteroscedasticity

The picture above shows the points spread randomly, do not form a clear / regular pattern, and are spread both above and below the number 0 on the $\mathrm{Y}$ axis so that "heteroscedasticity does not occur" in the regression model.

\subsection{Multiple Linear Regression}

The multiple regression equation can be seen from the value of the coefficient $B$ in the following table:

Table 3.6

\section{Regression Coefficient}

\begin{tabular}{|c|c|c|c|c|c|c|c|}
\hline Model & \multicolumn{2}{|c|}{ UnstandardizedCoefficients } & $\begin{array}{c}\text { Standardized } \\
\text { Coefficients }\end{array}$ & $\mathrm{t}$ & Sig & \multicolumn{2}{c|}{$\begin{array}{c}\text { Collinearity } \\
\text { Statistics }\end{array}$} \\
\hline & $\mathrm{B}$ & Std Error & Beta & & & Tolerance & VIF \\
\hline (Constant) & 2,738 & 3,273 & &, 834 &, 407 & & \\
\hline $\begin{array}{c}\text { Promotion } \\
\text { (X1) }\end{array}$ &, 474 &, 140 &, 409 & 3,383 &, 001 &, 337 & 2,969 \\
\hline $\begin{array}{c}\text { Ease of Use } \\
\text { (X2) }\end{array}$ &, 209 &, 134 &, 172 & 1,667 &, 003 &, 404 & 2,476 \\
\hline \multicolumn{2}{|l|}{$\begin{array}{l}\text { Trust (X3) } \\
\text { Dependent Variable : Purchase Decision }\end{array}$} &, 183 &, 228 & 1,835 &, 004 &, 195 & 5,136 \\
\hline
\end{tabular}

Source: Processed Research Data (2021)

From the calculation using a computer program using SPSS (Statistical Program For Social

Schedule) version 23.0, it can be obtained:

$$
\mathrm{a}=2.738
$$


Analysis Of Factors Affecting E-Commerce Customer Purchase Decisions

DOI: $10.54443 /$ morfai.v1i2.114

$$
\begin{aligned}
& \text { b1 }=0.474 \\
& \text { b2 }=0.209 \\
& \text { b3 }=0.262
\end{aligned}
$$
Trust) are:

So the linear multiple regression equations for the three predictors (Promotion, Ease of Use and

$$
\mathrm{Y}=2.738+0.474 \mathrm{X} 1+0.209 \mathrm{X} 2+0.262 \mathrm{X} 3
$$

The above equation shows that all independent variables (Promotion, Ease of Use and Trust) have a positive bi coefficient, meaning that all independent variables have a unidirectional relationship to the Y variable (Customer Purchase Decision). Promotion variable (X1) has the largest relative contribution between the two independent variables.

\subsection{Hypothesis Test}

\subsubsection{Partially Significant Test (Test)}

Testers of the relationship of independent variables $(\mathrm{X})$ to the dependent variable $(\mathrm{Y})$ can be

\begin{tabular}{|c|c|c|c|c|c|c|c|}
\hline \multirow[t]{2}{*}{ Model } & \multicolumn{2}{|c|}{ UnstandardizedCoefficients } & \multirow{2}{*}{$\begin{array}{l}\text { Standardized } \\
\text { Coefficients } \\
\text { Beta }\end{array}$} & \multirow[t]{2}{*}{$\mathrm{t}$} & \multirow[t]{2}{*}{ Sig } & \multicolumn{2}{|c|}{$\begin{array}{c}\text { Collinearity } \\
\text { Statistics }\end{array}$} \\
\hline & B & Std Error & & & & Tolerance & VIF \\
\hline (Constant) & 2,738 & 3,273 & & 834 & ,407 & & \\
\hline $\begin{array}{l}\text { Promotion } \\
\text { (X1) }\end{array}$ &, 474 &, 140 & 409 & 3,383 & 001 & ,337 & 2,969 \\
\hline $\begin{array}{c}\text { Ease of Use } \\
\text { (X2) }\end{array}$ & ,209 & ,134 & ,172 & 1,667 & ,003 & ,404 & 2,476 \\
\hline Trust (X3) & ,262 & ,183 & 228 & 1,835 & ,004 & ,195 & 5,136 \\
\hline
\end{tabular}
seen in the following table:

Table 3.7

Partially Significant Test (t Test)

Source: Processed Research Data (2021)

\section{1) Effect of Promotion on Purchase Decision}

Based on the t-test table data above, it can be seen that the acquisition of coefficients values: tcount $=3.383$ ttable $=1.660$

With decision making criteria:

Ho is rejected if: tcount $>$ ttable or - tcount $<-$ ttable at $=5 \%$,

$>$ Ho is accepted if: tcount ttable or - tcount -ttable

Based on the test results above, the Promotion variable (X1) obtained tcount of 3.383 with a significant value of 0.001 while the value of the provisions for 100 samples t-table was 1.660 with a significant value of 0.05 . In conclusion, tcount $3.383>$ ttable 1.660 with a significant value of 0.001 $<0.05$ then $\mathrm{Ho}$ is rejected and $\mathrm{Ha}$ is accepted, which means that partially Promotion (X1) has a significant effect on Purchase Decision (Y) at E-Commerce Shopee in Medan City. 


\section{TORFAI JOURNAL Multidiciplinary Output Research For Actual and International Issue}

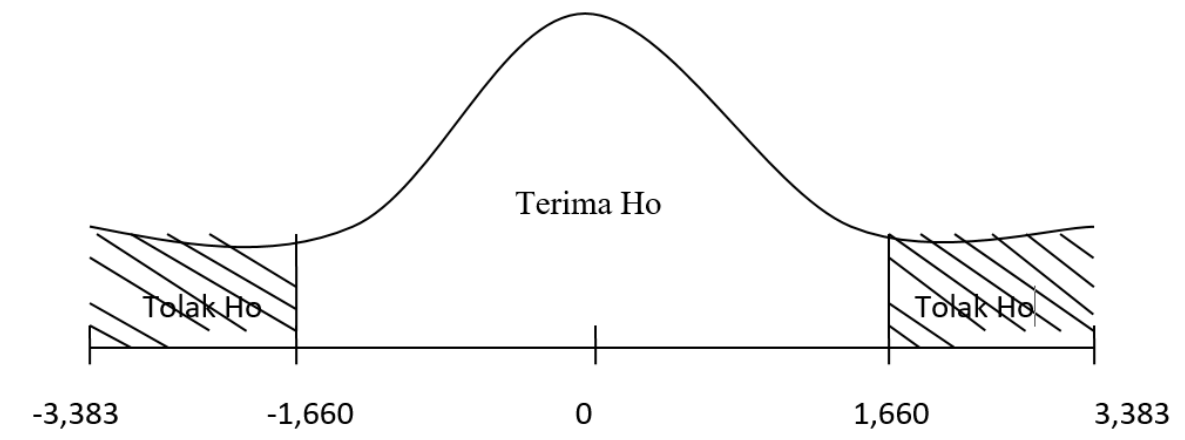

Source: Processed Research Data (2021)

Figure 3.4 Curve of $t$ test results (X1)

\section{2) The Effect of Ease of Use on Purchase Decisions}

Based on the t-test table data above, it can be seen that the acquisition of coefficients values: tcount $=1.667$ ttable $=1.660$

With decision making criteria:

$>$ Ho is rejected if: tcount $>$ ttable or - tcount $<-$ ttable at $=5 \%$,

$>$ Ho is accepted if: tcount ttable or - tcount -ttable

Ease of Use (X2) obtained tcount of 1.667 with a significant value of 0.003 while the value of the provisions for 100 samples ttable of 1.660 with a significant value of 0.05 . In conclusion, tcount 1.667 $>$ ttable 1.660 with a significant value of $0.003<0.05$ then Ho is rejected and Ha is accepted which means that partially Ease of Use (X2) has a significant effect on Customer Purchase Decisions (Y) at ECommerce Shopee in Medan City.

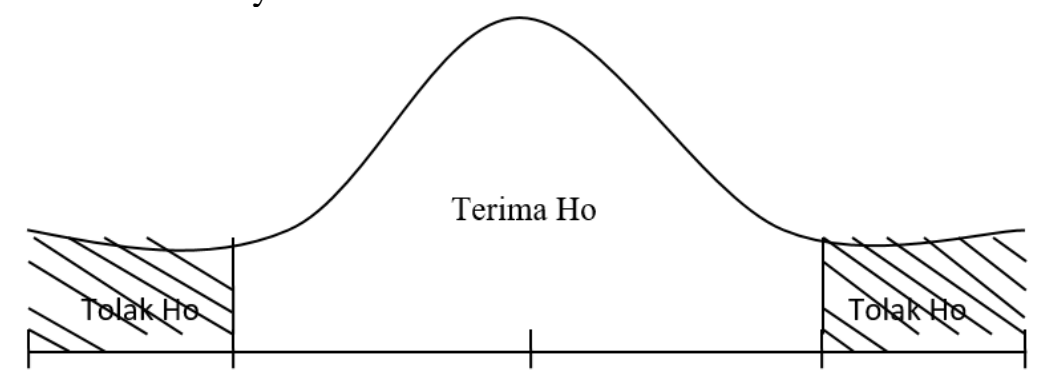
$-1,657$
$-1,660$
0
1,660
1,657

Source: Processed Research Data (2021)

Figure 3.5 Curve of t-test test results (X1)

\section{3) The Effect of Trust on Purchase Decisions}

Based on the t-test table data above, it can be seen that the acquisition of coefficients values: tcount $=1.835$ ttable $=1.660$

With decision making criteria:

$>$ Ho is rejected if: tcount $>$ ttable or - tcount $<-$ ttable at $=5 \%$,

$>$ Ho is accepted if: tcount ttable or - tcount -ttable

Confidence (X3) obtained tcount of 1.835 with a significant value of 0.004 while the value of the provisions for 100 samples of t-table was 1.660 with a significant value of 0.05 . In conclusion, tcount $1.835>$ ttable 1.660 with a significant value of $0.004<0.05$ then Ho is rejected and Ha is accepted which means that partially Trust (X3) has a significant effect on Customer Purchase Decisions (Y) at ECommerce Shopee in Medan City. 


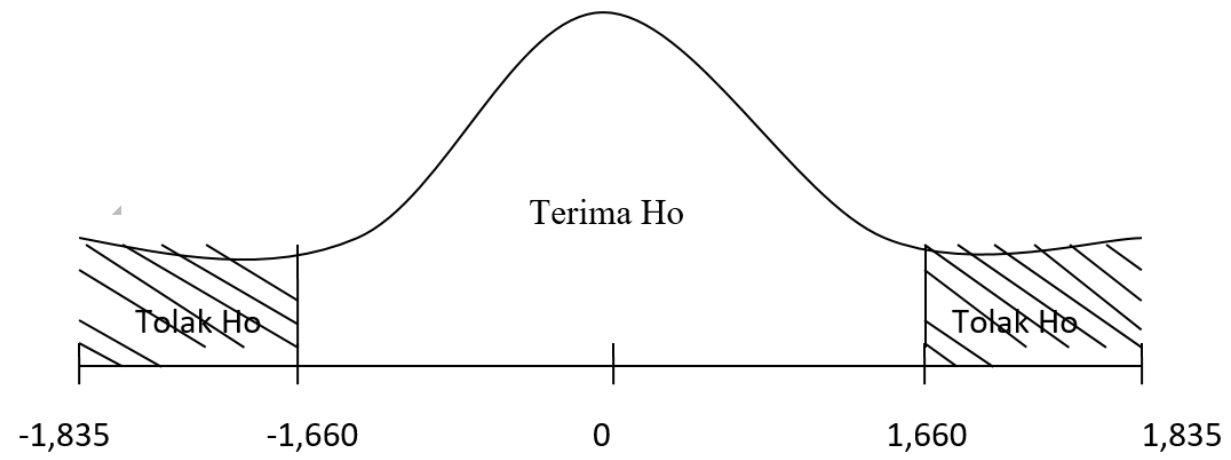

Source: Research Data Processed by IBM SPSS 23

Figure 3.6 Curve of $t$ Test Test Results (X3)

\subsubsection{Simultaneous Significant Test (Test F)}

Substantial hypotheses in this study are: Promotion (X1), Ease of Use (X2) and Trust (X3) affect the Purchase Decision variable (Y). In order to perform statistical testing, the substantial hypothesis is converted into a statistical hypothesis as follows:

Ho : $1=2=3=0$ \{if all coefficients are equal to zero, then Promotion (X1), Ease of Use (X2) and Trust (X3) have no significant effect on Purchase Decision (Y)\}.

Ha : One 0 \{ if one of the coefficients is not equal to zero, then Promotion (X1), Ease of Use (X2) and Trust (X3) have a significant effect on Purchase Decision (Y)\}.

The condition is that if the Sig value in the Anova table is $<\alpha 0.05$, then Ho is rejected, but if the Sig value is $>\alpha 0.05$, then Ho is accepted. The data needed to test the above hypothesis are as follows:

Table 3.8

\section{Simultaneous Significant Test (F Test)}

\begin{tabular}{|l|l|r|r|r|r|r|}
\hline \multicolumn{7}{|l|}{ ANOVA $^{\mathrm{a}}$} \\
\hline \multicolumn{2}{|l|}{ Model } & Sum of Squares & \multicolumn{1}{c|}{ df } & Mean Square & \multicolumn{1}{c|}{ F } & Sig. \\
\hline \multirow{2}{*}{1} & Regression & 391,388 & 3 & 130,463 & 35,784 &, $000^{\mathrm{b}}$ \\
& Residual & 350,002 & 96 & 3,646 & & \\
& Total & 741,390 & 99 & & & \\
\hline
\end{tabular}

a. Dependent Variable: Keputusan Pembelian

b. Predictors: (Constant), Kepercayaan (X3), Kemudahan Penggunaan (X2), Promosi (X1)

Source: Processed Research Data (2021)

Ftable $=$ Df $1=\mathrm{k}-1=3-1=2$, Df $2=$ nk $-1=100-3-1=96$ is 3.94 , Fcount $=35,784$

a. Fcount $>$ Ftable $=$ Ho is rejected, significant level is 0.05 (Sig.2 tailed 0.05)

b. Fcount $<$ Ftable $=$ Ho is accepted, significant level is 0.05 (Sig.2 tailed 0.05)

Based on table data 4.13. In the F test, the Fcount value is 35,784 with a significant value of 0.000 in Ftable for 100 samples with a significant 0.05 with a Ftable value of 3.94, then Fcount is 35,784 > Ftable 3.94 with a significant value of 0.000 below the 0.05 value which indicates that Promotion variables (X1), Ease of Use (X2) and Trust (X3) simultaneously affect the Purchase Decision (Y) at ECommerce Shopee in Medan City. 


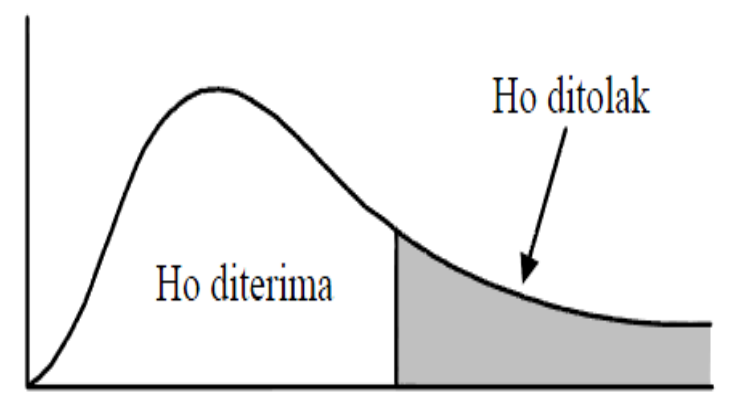

0

$3.94 \quad 35,784$

Source: Processed Research Data (2021)

Figure 3.7 Simultaneous Test F . Test

\subsection{Coefficient of Determination (R-Square)}

Furthermore, by looking at the R-Square will be able to see how the actual value of the contribution of the two independent variables to the dependent variable:

Table 3.9

\section{Coefficient of Determination}

\begin{tabular}{|l|r|r|r|r|r|}
\hline \multicolumn{2}{|c|}{ Model Summary $^{\text {b }}$} \\
\hline Model & $\mathrm{R}$ & R Square & $\begin{array}{c}\text { Adjusted R } \\
\text { Square }\end{array}$ & $\begin{array}{c}\text { Std. Error of the } \\
\text { Estimate }\end{array}$ & Durbin-Watson \\
\hline 1 &, $727^{\mathrm{a}}$ &, 528 &, 513 & 1,90941 & 2,094 \\
\hline
\end{tabular}

a. Predictors: (Constant), Kepercayaan (X3), Kemudahan Penggunaan (X2), Promosi (X1)

b. Dependent Variable: Keputusan Pembelian

Source: Research Data Processed by IBM SPSS 23

Through the table above, it can be seen that the R value is 0.727 and the R-Square is 0.528 or $52.80 \%$. From the R-Square value, it can be seen that together Promotion, Ease of Use and Trust have an influence of $52.80 \%$, while the remaining $38.1 \%$ is influenced by other factors outside this study.

\subsection{Discussion}

From the research results, it can be seen that all independent variables (Promotion, Ease of Use and Trust) have a positive $b$ coefficient, meaning that all independent variables have a direct influence on the Y variable (Purchase Decision). In more detail the results of the analysis and testing can be explained as follows:

\subsubsection{Effect of Promotion on Customer's Purchase Decision}

From the statistical test results Promotion (X1) has a positive and significant effect on Purchase Decisions (Y) at E-Commerce Shopee in Medan City. Due to the results of tcount (3.383) > ttable 
(1.660) with a significant value of $0.001<0.05$, Ho is rejected and Ha is accepted.

The results of this study are in line with previous research conducted by (Purnama et al., 2021) the research results show that promotion has a positive and significant effect on purchasing decisions.

The results of this study are in accordance with the theory put forward by (Ilham Rasyadi, 2017)that the Customer's Purchase Decision is influenced by the given Promotion. Promotion is one part of the marketing mix that is very important in a business. Promotion has an effect on purchasing decisions. This shows that promotion is something that needs to be considered by a company to attract the attention of consumers. In addition, promotions are also carried out to persuade potential buyers to make transactions with sellers in order to achieve the company's goal of making a profit.

\subsubsection{Effect of Ease of Use on Customer's Purchase Decision}

From the statistical test results, Ease of Use (X2) has a positive and significant effect on Purchase Decisions (Y) at E-Commerce Shopee in Medan City. Due to the results of tcount (1.667) > ttable (1.660) with a significant value of $0.003<0.05$ then Ho is rejected and Ha accepted.

The results of this study are in line with previous research conducted by (Alistriwahyuni, 2019) the results of the study indicate that Ease of Use has a positive and significant effect on purchasing decisions.

The results of this study are in accordance with the theory put forward by (Davis, 1989)that employees' Purchase Decisions are influenced by Ease of Use. Ease of use can be interpreted as the extent to which individuals believe that using a particular system or technology will be free from difficulties and a great effort. Ease of use is one of the factors that influence purchasing decisions. If an individual believes that a system is easy to use, then he will use it, and vice versa. As previously explained, the ease of use variable aims to make it easier for users.

\subsubsection{The Effect of Trust on Customers' Purchase Decisions}

From the results of the statistical test, Trust (X3) has a positive and significant effect on Purchase Decisions (Y) at E-Commerce Shopee in Medan City. Due to the results of tcount (1.835) > ttable (1.660) with a significant value of $0.004<0.05$, Ho is rejected and $\mathrm{Ha}$ is accepted.

The results of this study are in line with previous research conducted by (Lestari \& Sri Setyo Iriani, 2018) the research results show that trust has a positive and significant effect on purchasing decisions.

The results of this study are in accordance with the theory put forward by (Hendra. \& Amin, 2019)defines Trust, including a very important thing in carrying out a transaction, both online and inperson transactions. Consumer trust is a belief that is believed by a consumer that other people have honesty and can be trusted and the person he trusts will carry out all his obligations related to the agreed transaction in accordance with consumer expectations.

\subsubsection{Effect of Promotion, Ease of Use and Trust on Customer's Purchase Decision}

Simultaneous testing shows that Promotion (X1), Ease of Use (X2) and Trust (X3) variables have a significant effect on Customer Purchase Decisions (Y) at Shopee E-Commerce in Medan City. Due to the results of Fcount (35.784) > Ftable (3.94) with a significant value of 0.05, Ho is rejected and Ha is accepted.

With an R Square value of 0.528 or $52.80 \%$ which means that the relationship between Customer Purchase Decision (Y) and Promotion (X1), Ease of Use (X2) and Trust (X3) is Medium, while the remaining $47.2 \%$ variables others not examined by this study.

\section{CONCLUSION}

Based on the data obtained in research regarding the Effect of Promotion, Ease of Use and Trust on Purchase Decisions at E-Commerce Shopee in Medan City, the respondents in this study amounted to 100 customers, then analyzed, the conclusions are as follows: 
1. Partially Promotion has a positive and significant effect on Purchase Decisions

2. Partially Ease of Use has a positive and significant effect on Purchase Decisions

3. Partially Trust has a positive and significant effect on Purchase Decisions

4. Simultaneously Promotion, Ease of Use and Trust have a positive and significant effect on Purchase Decisions

\section{REFERENCE}

Alistriwahyuni, N. (2019). The Effect of Sales Promotion, Ease of Use, and i-Saku Service Features on Purchase Decisions for i-Saku Users at Indomaret. Journal of Business Administration Education (JPTN), 07(02), 473-478.

Ayuningtiyas, K., \& Gunawan, H. (2018). The Effect of Trust, Ease and Quality of Information on Online Purchase Decisions in the Bukalapak Application on Batam State Polytechnic Students. Journal of Applied Business Administration, 2(1), 152-165. https://doi.org/10.30871/jaba.v2i1.763

Bahri, S., \& Listiorini. (2019). The Influence of Perceived Usability, Perception of Ease, Perception of Security and Confidentiality and Perception of Speed on Taxpayer Interest in Using E-Filing at KPP Pratama Binjai. Journal of Accounting and Business Research, 19(2), 159-170.

Catriana, E. (2020, September). Shopee Books 260 Million Transactions in the Second Quarter. kompas.com.

Davis, FD (1989). Perceived Usefulness, Perceived Ease of Use, and User Acceptance of Information Technology. MIS Quarterly, 13(3), 319-340. https://doi.org/10.5962/bhl.title.33621

Hanum, F., Purnama, NI, \& Harahap, SH (2021). Analysis of Service Quality and Grab Promotion on Consumer Satisfaction at University of Muhammadiyah North Sumatra Students Using Grab. Journal of AKMAMI (Accounting, Management, Economics).

Hendra. \& Amin, A. . (2019). Analysis of effect of trust, ease, and promotion on online purchase decision of Lzada.co.id (Case study on Pelita Indonesia students). Journal of Accounting, Entrepreneurship and Business.

Istiarni, PRD, \& Hadiprajitno, PB (2014). Analysis of the Effect of Perceived Benefits, Ease of Use, and Credibility on Interest in Internet Banking Repeat Use With Attitude of Use as an Intervening Variable (Empirical Study: Customers of Internet Banking Services in Indonesia). Diponegoro Journal of Accounting, 03(02), 1-10.

Jayani, DH (2020). Map of Indonesia's E-Commerce Competition in the Second Quarter-2020. databox. Jayanti, RD (2015). The Effect of Price and Trust on Online Purchase Decisions (Case Study on Harapan Maulina Hijab Jombang). Journal of Existing, 10(1), 13-27.

Kotler, P., \& Armstrong, G. (2001). Marketing Principles, Edition 12, Volume 1. Erlangga.

Lestari, NA, \& Sri Setyo Iriani. (2018). The effect of trust and ease of transactions on online purchasing decisions on the Mataharimall.com site. Journal of Management Science, 6(1), 1-8.

Marlius, D. (2017). Purchasing Decision Based on Biological Factors and Marketing Mix PT. Intercom Mobilindo Padang. Pundi Journal.

Prayudha, BT, \& Suwitho. (2019). The Effect of Ease, Risk, and Quality of Information on Online Purchase Decisions at Tokopedia.Com. Journal of Management Science and Research.

Purnama, NI, Ramadhan, A., \& Kurniawan, R. (2021). The Influence of Price, Promotion and Product Quality On Samsung Smartphone Purchase Decisions in UMSU Students. Proceedings of the International Seminar on Islamic Studies.

Putra, E. (2019). The Influence of Promotion and Brand Image Toward Purchase Decision of Honda Vario. Journal of Economic Appreciation.

Rasyadi, I. (2017). The Influence of Promotion and Quality of Service on Consumer Interests of Mitsubishi Pajero Cars (Case of Dealer of Pekan Perkasa Berlian Motor Pekanbaru). Let's FISIP.

Rasyadi, Ilham. (2017). The Influence of Promotion and Quality of Service on Consumer Interests of 
Mitsubishi Pajero Cars (Case of Dealer of Pekan Perkasa Berlian Motor Pekanbaru). LET'S FISIP, $4(1), 1-13$.

Sandu, S., \& Sodik, MA (2015). Basic Research Methodology (1 ed.). Media Literacy Publishing.

Septiani, F. (2018). The Influence of Promotions and Products on Purchase Interest (At PT. Asuransi Jiwa Recapital in Jakarta). Civilian Journal: Science, Technology, And Humanities.

Sugiyono. (2017). Educational Research Methodology Quantitative, Qualitative, and R\&D Approach (12 ed.). Alphabet.

Suhardi, D., \& Taufik, N. (2018). The Analysis of Ease of Use, Trust, and Website Quality towards Purchasing Decision in Lazada.co.id. Indonesian Journal Of Business And Economics, 1(1), 38 48. https://doi.org/10.25134/ijbe.v1i1.1358

Suleman, D., Zuniarti, I., \& Sabil. (2019). Consumer Decisions toward Fashion Product Shopping in Indonesia: The effects of Attitude, Perception of Ease of Use, Usefulness, and Trust. Management Dynamics in the Knowledge Economy, 7(2), 133-146. https://doi.org/10.25019/mdke/7.2.01

Private, B., \& Irawan, I. (2008). Modern Marketing Management. Liberty.

Tajudin, MH, \& Mulazaid, AS (2017). The Effect of Promotion, Trust and Brand Awareness on Customer Decisions to Use Hajj Savings Products (Mabrur) Bank Syariah Mandiri Kcp. Sawangan Depok City. Journal of Islamic Economics.

Yuliawan, E., Siagian, H., \& Willis, L. (2018). Analysis of the Influence of Trust, Ease and Service Quality Factors on Purchase Decisions at Zalora Indonesia's Online Shop (Study of Management Study Program Students, STIE Mikroskil Medan). Journal of Economics and Entrepreneurship, 12(1), 34-49. https://doi.org/10.33558/optimal.v12i1.11016 
